\title{
Women Empowerment through Self Help Groups: Case Study in Jalandhar District of Punjab
}

\author{
Lakhwinder Kaur*, Divya Sachan and Arjun Sulibhavimath
}

Dept. of Extension Education and Communication Management, PAU, Ludhiana, Punjab (141 001), India

\section{Corresponding Author}

Lakhwinder Kaur

e-mail: lakhwinder.pau@gmail.com

\author{
Article History \\ Manuscript No. AR1797e \\ Received in $15^{\text {th }}$ February, 2017 \\ Received in revised form $28^{\text {th }}$ March, 2017 \\ Accepted in final form $7^{\text {th }}$ April, 2017
}

\begin{abstract}
Rural women today have been suffering a lot due to the feeling of helplessness and lack of decision-making capabilities in financial matters. Self-help groups (SHGs) are the most recent development for them which could enable them to come forward and make them self-dependent and self-employed. The present study was conducted in Jalandhar district of Punjab state in 2014 by focused on in-depth study of two groups i.e., Mian mamli and Nari shakti formed by Pahal NGO. The present study revealed that on an average fifty per cent of the members were young, matriculates, labourers, belonged to SC category, earned up to sixty five thousand per annum. Majority of the women (>90\%) joined the group for a variety of reasons like to supplement family income, to develop social ties, to avail economic benefit, to develop habit of savings and to get easy access for credit which resulted in increased their income and savings. The study further revealed that majority of the members of self-help groups participated in various training programmes organized by promoting agency and Krishi Vigyan Kendra as a result of which women who never used to step outside the four walls of their home became business women and started supplementing their family income by adopting various entrepreneurial activities viz. candle and surf making, pickle formation and processing of fruits and vegetables etc.
\end{abstract}

Keywords: NGO, women, income, empowerment, self-help groups

\section{Introduction}

The need for empowerment is felt everywhere in India especially women empowerment. Empowerment by the way of participation in SHG can bring enviable change and enhancement in the living conditions of women in poor and developing nations. It is a multi- dimensional social process that helps people gain control over their own lives and in their society by acting on issues that they consider as important. It is a process in which women challenge the existing norms and culture, to effectively promote their well being (Narang 2012, Thangamani and Muthuslevi, 2013). The balance of power between men and women is equal and neither party has dominance over the other (Khan et al., 2010). Women empowerment is one of the important issue of today's world. Despite a major contribution in the development process, female population has a low status as compared to men, specifically in developing world. So there is necessitate to give equal status to women. (Khan et al., 2010). One of the powerful approach to women empowerment is the formation of self-help group among women. The term self-help group is operationally defined as informal groups whose members have a common perception of need and importance towards collective action (Tekale et al., 2014). The social empowerment of women includes better status in the family, freedom for marriage, right to property, social mobility, social freedom, family welfare, social transformation and gender equity. The economic empowerment of women includes ownership and control of research right to property, employability, improvement in the standard of living, fulfilment of basic needs, entrepreneurship development and improvement of bargaining power of women (Srinivasa and Siddagowda, 2015) Women belonging to low socio-economic groups generally face financial crisis to fulfill daily needs which forms a vicious cycle of financial problems, malnutrition, lack of education and poor living conditions etc. Women empowerment is the key component in mitigating poverty and related problems. Due to globalization, emancipation of women in India has created economic opportunities and woman entrepreneur have emerged as a significant pillar in booming nation's economy. Making of self-help groups is the best way to institutionalize economic empowerment among women. Self- help group not only instigate women to grow their savings but also give access to facilities of credit from various banks (Husain and Nair, 2006). Self-help groups are village based financial intermediary usually composed of 15-20 local women who are supported by government or NGO's. Micro finance through 
self help group has become a ladder for the poor to bring them up not only economically but also socially, mentally and attitudinally (Sharma et al., 2012).

PAHAL is a voluntary organization promoted by like-minded Educationists, Doctors, Legal experts, Technocrats, Dynamic entrepreneurs, enthusiastic students and effervescent youth to bring a perceptible change in the present social set-up. PAHAL expresses the essence of living and upholds the need to appreciate the other man's point of view and to show consideration for fellow human beings. It also holds that the welfare of an individual is ultimately dependent on the welfare of the society as a whole. This voluntary non-governmental organization was launched in Sept. 1996. It got registered on $6^{\text {th }}$ September, 1996 under Societies Registration Act 1860. It was inaugurated on $13^{\text {th }}$ of Sept. 1996, after organizing its first activity, a Blood Donation Camp on 12.09.96. PAHAL formed various self-help groups to help rural women to be self-dependent with the help of various extension approaches. Kaur and Kalra (2015) in their study found that extension approaches like group discussion, trainings and group meetings were 'always used by the managers of promoting agencies for empowering the members. The present study addresses the women empowerment through self-help groups in Jalandhar.

The study by Kaur and Kalra (2014) found that majority of the respondents $(83.33 \%)$ reported that linkages with line departments and regularity in savings $(75 \%)$ were the major strengthening points while half of the respondents observed group crisis and non-cooperation of the family members as the major weaknesses that hindered the faithful performance of the group. Another study conducted by Shettar (2015) reveals that women of India are relatively disempowered and they enjoy somewhat lower status than that of men in spite of many efforts undertaken by Government. It is found that acceptance of unequal gender norms by women are still prevailing in the society. The study concludes by an observation that access to Education, Employment and Change in Social Structure are only the enabling factors to Women Empowerment.

\section{Material and Methods}

The present study was conducted in Jalandhar district of Punjab state in 2014. Two groups' viz., Mian mamli and Nari Shakti formed by promoting agency (PAHAL) were selected for the collection of required information for the study. Case study method was used to get in-depth and clear insights on overall quality of life of SHG members. The data were collected with the help of interview schedule and analysed with the help of frequency and percentages.

\section{Results and Discussion}

The data in Table 1 revealed that $51.43 \%$ of the members
Table 1: Profile of the members of self-help groups (SHGs) in Punjab

\begin{tabular}{|c|c|c|c|c|c|c|c|}
\hline \multirow{2}{*}{$\begin{array}{l}\text { Socio- } \\
\text { personal } \\
\text { charac- } \\
\text { teristics }\end{array}$} & \multirow[t]{2}{*}{ Cat } & \multicolumn{2}{|c|}{$\begin{array}{l}\text { Mian } \\
\text { Mamli } \\
(\mathrm{n}=20)\end{array}$} & \multicolumn{2}{|c|}{$\begin{array}{c}\text { Nari } \\
\text { Shakti } \\
(\mathrm{n}=15)\end{array}$} & \multicolumn{2}{|c|}{$\begin{array}{c}\text { Overall } \\
(\mathrm{n}=35)\end{array}$} \\
\hline & & Fre & Per & Fre & Per & Fre & Per \\
\hline \multirow{3}{*}{$\begin{array}{l}\text { Age } \\
\text { (years) }\end{array}$} & $25-35$ & 11 & 55 & 7 & 46.67 & 18 & 51.43 \\
\hline & $36-45$ & 7 & 35 & 5 & 33.33 & 12 & 34.29 \\
\hline & $46-55$ & 2 & 10 & 3 & 20 & 5 & 14.29 \\
\hline \multirow[t]{4}{*}{ Education } & $\begin{array}{l}\text { Illiter- } \\
\text { ate }\end{array}$ & 1 & 5 & 4 & 26.67 & 5 & 14.29 \\
\hline & Primary & 1 & 5 & 2 & 13.33 & 3 & 8.57 \\
\hline & Middle & 2 & 10 & 6 & 40 & 8 & 22.86 \\
\hline & Matric & 16 & 80 & 3 & 20 & 19 & 54.29 \\
\hline \multirow{2}{*}{$\begin{array}{l}\text { Occupa- } \\
\text { tion of } \\
\text { family }\end{array}$} & Labour & 14 & 70 & 12 & 80 & 26 & 74.29 \\
\hline & $\begin{array}{l}\text { Arti- } \\
\text { sans }\end{array}$ & 6 & 30 & 3 & 20 & 9 & 25.71 \\
\hline \multirow[t]{3}{*}{ Caste } & General & 5 & 25 & 2 & 13.33 & 7 & 20 \\
\hline & SC & 11 & 55 & 12 & 80 & 23 & 65.71 \\
\hline & $\mathrm{BC}$ & 4 & 20 & 1 & 6.67 & 5 & 14.29 \\
\hline \multirow{2}{*}{$\begin{array}{l}\text { Family } \\
\text { type }\end{array}$} & Nuclear & 16 & 80 & 11 & 73.33 & 27 & 77.14 \\
\hline & Joint & 4 & 20 & 4 & 26.67 & 8 & 22.86 \\
\hline \multirow{2}{*}{$\begin{array}{l}\text { Family } \\
\text { size }\end{array}$} & $4-6$ & 14 & 70 & 12 & 80 & 26 & 74.29 \\
\hline & $6-8$ & 6 & 30 & 3 & 20 & 9 & 25.71 \\
\hline \multirow{3}{*}{$\begin{array}{l}\text { Family } \\
\text { income (₹ } \\
\text { annum }^{-1} \text { ) }\end{array}$} & $\begin{array}{l}\text { Upto ₹ } \\
65000\end{array}$ & 12 & 60 & 7 & 46.67 & 19 & 54.29 \\
\hline & $\begin{array}{c}₹ \\
65000- \\
110000\end{array}$ & 7 & 35 & 6 & 40 & 13 & 37.14 \\
\hline & $\begin{array}{c}\text { Above } \\
₹ \\
110000\end{array}$ & 1 & 5 & 2 & 13.33 & 3 & 8.57 \\
\hline
\end{tabular}

Cat: Category; Fre: Frequency; Per: Percentage (\%);

belonged to the age group of 25-35 years. This may be due to the reason that young women are energetic and having strong urge to achieve their goal, there-in participating actively in the group. However $34.29 \%$ of the members belonged to the age group of $36-45$ years while $14.29 \%$ of the members belonged to the age group of $46-55$ years. Regarding education, more than $50 \%$ of the members $(54.29 \%)$ were literate having educational qualification up to Matric while $22.86 \%$ of the members were studied up to middle level. Majority of the members were labourers whereas $25.71 \%$ members were artisans (painters, carpenters etc.).

Further look at Table 1 revealed that majority (65.71\%) of 
the members of group belonged to SC category. It may be to the reason that these women were poor and joined the group to improve their economic conditions. These results were in conformity with those of Sharma et al. (2012), Gupta and Singh (2012); Lokhande (2013). 20\% and 14\% member's belonged to general and backward category. An overview of the family type revealed that majority (77.14\%) of the member's belonged to nuclear family whereas $22.86 \%$ of the members belonged to joint family. Regarding family size, $74.29 \%$ members had a family size of 4-6 members while $25.71 \%$ had a family size of 6-8 members.

Family income was measured in rupees per annum and data revealed that most of members (54.29\%) of these groups earned up to ₹ 65/- thousand annum ${ }^{-1}$. This may be too due to the reason that most of the members of self-help groups belonged to poor families. More than one-third members earned in the range of ₹ 6500-110000/- while only $8.57 \%$ members earned more than ₹ 110000/- annum ${ }^{-1}$.

A scrutiny of the data in Table 2 indicated that a large majority (91.43\%) had low level of social participation. The reason could

Table 2: Distribution of the respondents based on their social participation, extension contacts and mass media exposure

\begin{tabular}{|c|c|c|c|c|c|c|c|}
\hline \multirow{2}{*}{$\begin{array}{l}\text { Socio- } \\
\text { per- } \\
\text { sonal } \\
\text { charac- } \\
\text { teristics }\end{array}$} & \multirow[t]{2}{*}{ Cat } & \multicolumn{2}{|c|}{$\begin{array}{l}\text { Mian } \\
\text { Mamli } \\
(n=20)\end{array}$} & \multicolumn{2}{|c|}{$\begin{array}{l}\text { Nari Shakti } \\
\qquad(n=15)\end{array}$} & \multicolumn{2}{|c|}{$\begin{array}{l}\text { Overall } \\
(n=35)\end{array}$} \\
\hline & & Fre & Per & Fre & Per & Fre & Per \\
\hline \multirow{2}{*}{$\begin{array}{l}\text { Social } \\
\text { partici- } \\
\text { pation }\end{array}$} & Low (0-2) & 17 & 85 & 15 & 100 & 32 & 91.43 \\
\hline & $\begin{array}{l}\text { Medium } \\
(2-4)\end{array}$ & 2 & 10 & - & - & 2 & 5.71 \\
\hline \multirow{4}{*}{$\begin{array}{l}\text { Exten- } \\
\text { sion } \\
\text { contacts }\end{array}$} & High (4-6) & 1 & 5 & - & - & 1 & 2.86 \\
\hline & Low (0-2) & 1 & 5 & 1 & 6.67 & 2 & 5.71 \\
\hline & $\begin{array}{l}\text { Medium } \\
(2-4)\end{array}$ & 10 & 50 & 1 & 6.67 & 11 & 31.43 \\
\hline & High (4-6) & 9 & 45 & 13 & 86.66 & 22 & 62.86 \\
\hline \multirow{3}{*}{$\begin{array}{l}\text { Mass } \\
\text { media } \\
\text { expo- } \\
\text { sure }\end{array}$} & Low (0-2) & 7 & 35 & 3 & 20 & 10 & 28.57 \\
\hline & $\begin{array}{l}\text { Medium } \\
(2-4)\end{array}$ & 11 & 55 & 12 & 80 & 23 & 65.71 \\
\hline & High (4-6) & 2 & 10 & - & - & 2 & 5.71 \\
\hline
\end{tabular}

be that most of these members belonged to schedule caste family and not interested in becoming member of Panchayat, Mahila mandals, NGOs and Welfare societies.

It can be further noted that frequency of contact made by the members (62.86\%) with the extension personnel was 'high' in the group whereas $31.43 \%$ and $5.71 \%$ members was found to be 'medium' and 'low' for seeking information regarding self-help groups. Mass media exposure to gain information regarding development work being carried out by different agencies and groups was found to be medium (6\%) followed by low $(28.57 \%)$ and high $(5.71 \%)$ respectively.

PAHAL (NGO) took initiative to serve the needy people with the collaboration of NABARD, Pahal, in the field of socioeconomic development of the marginalized sections of the people were successful in forming large number of self-help groups. We identified two self-help groups i.e., Mian Mamli and Nari Shakti established in 2012 and 2013 respectively. These groups started voluntarily with 15 active members in the Mian Mamli (2012); Nari Shakti (2013) with aim to socialize and achieve economic self-sufficiency. These groups adopted various income generating activities to achieve financial selfreliance like decorative candle making, surf making, pickle formation and preparation of mango chuney. The leader controlled all the group activity was selected by election (Mian mamli) and with the consent of group members (Nari shakti) for a period of one year.

Meetings of mian mamli self-help group were observed to be common phenomena which was conducted fortnightly at gurudwara while nari shakti SHG conducted four meetings in a month at temple. Attendance of group members to discuss group activities was $85 \%$ in Mian mamli and $90 \%$ in Nari shakti. The penalty of $₹ 10$ were imposed to absentee in meetings in Nari shakti group. The record of their meetings was complete and up to date. Nari Shakti took loan of ₹ 40,000/- from Central Co-operative bank, Jalandhar at $2 \%$ rate of interest per month for purchase of raw materials. There were regular transactions between the bank and the group. Micro-credit not only helped rural people attain improved economic status but also led to social cohesion and women's empowerment (Gupta and Singh, 2012; Kalra et al., 2012). The major strengths of these groups were its ability to unite and market the products collectively. One of the basic principles of SHGs is that even the very poor may save small amounts. Regarding mobilization of financial resources, monthly savings of ₹ 100 were kept together in the Bank in the name of SHG which could be used by the women members for inter loaning among the members in times of emergencies (Table 3).

Training is concerned with developing a particular skill among members of self-help groups to a desired standard by instruction and practice. It is noticed from Table 4 that PAHAL conducted training on candle making whereas KVK, Jalandhar gave training to members of self-help groups on detergent making, processing of seasonal fruits and vegetables.

The data in Table 5 revealed that a large majority (94.28\%) of the members joined the group for a reason to supplement family income and to develop social ties. Furthermore $82.87 \%$ of the members joined the group to avail economic benefit, to develop habit of savings and to get easy access for credit. The others reasons for enrolling as a member of self-help groups 
Table 3: General information of the self-help groups of Punjab

\begin{tabular}{|c|c|c|}
\hline Name of group & Mian mamli & Nari shakti \\
\hline Year of establishment & 2012 & 2013 \\
\hline Year of registration & 2012 & 2013 \\
\hline Formation of group & PAHAL (NGO) & PAHAL (NGO) \\
\hline \multirow[t]{2}{*}{ Group size } & 201213 & 20 \\
\hline & 201315 & 15 \\
\hline Reasons for discontinuance & & $\begin{array}{l}\text { Non-payment by the members Non-cooperation of } \\
\text { family }\end{array}$ \\
\hline Entrepreneurial activity & $\begin{array}{l}\text { Candle making, surf mak- } \\
\text { ing }\end{array}$ & Candle making, pickle formation and mango chutney \\
\hline Selection of leader & Election & Consensus \\
\hline Term of leader & One year & One year \\
\hline \multicolumn{3}{|l|}{ Membership fee } \\
\hline Venue of meeting & Gurdwara & Temple \\
\hline Duration & Fortnightly & 4 meetings in a month \\
\hline Attendance $(n=10)$ & $85 \%$ & $90 \%$ \\
\hline $\begin{array}{l}\text { Action taken for not attending } \\
\text { meeting }\end{array}$ & No action taken & Fine of ₹ $10 /$ meeting \\
\hline Record of meeting & Complete and up to date & Complete and up to date \\
\hline Maintenance of record & Group leader & Group leader \\
\hline Purpose of loan & - & Purchase of raw materials \\
\hline Amount of loan taken for group & - & ₹ 40,000/- \\
\hline Name of bank & - & Central Co-operative Bank, Jalandhar \\
\hline Rate of interest of bank & - & $2 \%$ per month \\
\hline Payment of instalment & - & Regularly \\
\hline Getting of loan & - & Easily \\
\hline Loan utilized for said purpose & - & Yes \\
\hline Inter loaning & $2 \%$ rate of interest & $2 \%$ rate of interest \\
\hline Marketing of products & Collectively & Collectively \\
\hline Nature of production & demand basis & demand basis \\
\hline Monthly saving of the group & $₹ 100$ member $^{-1}$ & $₹ 100$ member $^{-1}$ \\
\hline
\end{tabular}

Table 4: Distribution of respondents based on training attended by them

\begin{tabular}{|c|c|c|c|c|}
\hline $\begin{array}{l}\text { Name of } \\
\text { the self- } \\
\text { help groups }\end{array}$ & Name of training & $\begin{array}{l}\text { Dura- } \\
\text { tion }\end{array}$ & $\mathrm{CB}$ & $\begin{array}{l}\text { Ben- } \\
\text { eficia- } \\
\text { ries }\end{array}$ \\
\hline \multirow{2}{*}{$\begin{array}{l}\text { Mian Mamli } \\
(n=20)\end{array}$} & Candle making & 2 days & PJ & 11 \\
\hline & Detergent making & 1 day & $\mathrm{KJ}$ & 18 \\
\hline \multirow{2}{*}{$\begin{array}{l}\text { Nari Shakti } \\
(n=15)\end{array}$} & Candle making & 2 days & PJ & 12 \\
\hline & $\begin{array}{l}\text { Processing of seasonal } \\
\text { fruits and vegetables }\end{array}$ & 1 day & $\mathrm{KJ}$ & 10 \\
\hline
\end{tabular}

CB: Conducted by; PJ: Pahal, Jalandhar; KV: KVK, Jalandhar were to repay old debts (71.42\%), to overcome exploitation from money lenders (54.28\%) and to get employment opportunities (51.42\%).

For the improvement in standard of living, income acts as a major determinant. An overview of the monthly income in Table 6 revealed that as many as sixty five per cent of the members increased their income in the range of ₹ 1000-1500 month ${ }^{-1}$ while $25 \%$ of the members increased their income in the range of ₹ 1500-2000 month $^{-1}$ before and after joining the groups. This shows that these two groups were efficient and grown up enough for applying continuous efforts to organise various entrepreneurial activities. The findings were in line with study conducted by Selvi and Shanmughun (2016) who 


\begin{tabular}{lccc}
\hline Table 5: Reasons for enrolling as a member of self-help groups \\
\hline Reasons & $\begin{array}{c}\text { Mian Mamli } \\
(\mathrm{n}=20) \mathrm{f}\end{array}$ & $\begin{array}{c}\text { Nari Shakti } \\
(\mathrm{n}=15) \mathrm{f}\end{array}$ & $\begin{array}{c}\text { Overall } \\
(\mathrm{n}=35) \mathrm{f}\end{array}$ \\
\hline Supplement family & 19 & 14 & 33 \\
income & -95 & -93.34 & -94.28 \\
Develop social ties & 19 & 14 & 33 \\
& -95 & -93.33 & -94.28 \\
Economic benefit & 18 & 11 & 29 \\
& -90 & & -82.87 \\
Easy access to credit & 15 & 14 & 29 \\
& -75 & -93.33 & -82.87 \\
Employment & 9 & 9 & 18 \\
opportunities & -45 & -60 & -51.42 \\
Overcome exploitation & 10 & 9 & 19 \\
from money lenders & -50 & -60 & -54.28 \\
Develop habit of & 19 & 10 & 29 \\
savings & -95 & -66.67 & -82.87 \\
Repay old debts & 15 & 10 & 25 \\
& -75 & -66.67 & -71.42 \\
\hline
\end{tabular}

Table 6: Income generation and monthly savings of women of various self-help groups

\begin{tabular}{lccc}
\hline $\begin{array}{l}\text { Increase in } \\
\text { monthly income } \\
\left(₹ \text { month }{ }^{-1}\right)\end{array}$ & $\begin{array}{c}\text { Mian Mamli } \\
(\mathrm{n}=20) \mathrm{f}\end{array}$ & $\begin{array}{c}\text { Nari Shakti } \\
(\mathrm{n}=15) \mathrm{f}\end{array}$ & $\begin{array}{c}\text { Overall } \\
(\mathrm{n}=35) \mathrm{f}\end{array}$ \\
\hline $500-1000$ & $3(15.00)$ & $2(13.33)$ & $5(14.28)$ \\
$1000-1500$ & $13(65.00)$ & $10(66.67)$ & $23(65.71)$ \\
$1500-2000$ & $4(20.00)$ & $3(20.00)$ & $7(20)$ \\
Increase in monthly savings (₹ month $\left.{ }^{-1}\right)$ & \\
\hline $50-100$ & $9(45.00)$ & $6(40.00)$ & $15(42.85)$ \\
$100-150$ & $7(35.00)$ & $7(46.67)$ & $14(40)$ \\
$150-200$ & $4(20.00)$ & $2(13.33)$ & $6(17.14)$ \\
\hline
\end{tabular}

reported that income of members has increased after joining self-help groups.

As regards to the mobilization of financial resources, savings has been given importance by the group members. It can be noted that $42.85 \%$ of the members increased monthly savings in the range of $₹ 50-100$ while $40 \%$ of members increased monthly savings to the tune of ₹ 100-200. The results of the study pointed out that the incremental income not only enhanced the productive expenditure of family but also promoted the savings. The findings were supported by Sharma and Varma, 2008.

\section{Conclusion}

Self-help group is an important tool which helps the rural women of Jalandhar district to acquire power for their selfsupportive life. Thus formation of Mian mamli and Nari shakti self-help groups is a path breaking initiative that can transform the lives of number of families members of these groups. SHG approach has emerged as a successful strategy for women in present time. The study concluded that women play an important role in supplementing family income by adopting various entrepreneurial activities viz. candle and surf making, pickle formation and processing of fruits and vegetables etc.

\section{Further Research}

A wider study may be planned by taking into consideration groups of other regions of Punjab. An effort should be made to study the case of other groups formed by Pahal right from formation stage to self helping stage.

\section{Acknowledgement}

The authors acknowledged to the women of the rural areas who have given significant information about functioning of their groups. The authors further acknowledge PAHAL for their support to provide of list of self help groups formed by them.

\section{References}

Gupta, S., Singh, S.K., 2012. Economic security among rural women through self-help groups: An analytical study. Indian Research Journal of Extension Education 12(2), 117-120.

Husain, A.S., Nair, A.S., 2006. Women empowerment through 'Kudumbashree' projects of Kerala- a micro level analysis. Manage Extension Research Review 7(2), 23-43.

Kalra, R.K., Anil, B., Siddique, K.H.M., Tonts, M., 2012. Self-help Groups in Indian Agriculture: A case study of Farmer Groups in Punjab, Northern India. Journal of Sustainable Agriculture doi: 10.1080/10440046. 2012.719853-1-11.

Khan, T.M., Mann, A.A., Zafar, M.I., Hashmi, N., Akhtar, S., 2010. Determinants of women empowerment: a case study from district Rawalpindi, Pakistan. Pakistan Journal of Science 62, 47-49.

Kaur, L., Kalra, R.K., 2014. Swot Analysis of the Self Help Groups. Indian journal of Extension Education 50(1), 80-83.

Kaur, L., Kalra, R.K., 2015. A study of extension approaches used by the managers in managing the self help groups. Indian Journal of Social Research 56(6), 931-39.

Lokhande, M.A., 2013. Micro Finance for Women Empowerment-A Study of Self-help Groups-Bank Linkage Programme. International Center for Business Research 2, 1-8.

Narang, U., 2012 Self help group: an effective approach to women empowerment in India. International Journal of Social Science \& Interdisciplinary Research 1, 8-14. 
Sharma, A., Roy, B., Chakravorty, D., 2012. Potential of selfhelp groups as an Entrepreneur: a case study form Uttar Dinajpur district of West Bengal. Journal of Social Science 30, 83-87.

Selvi, R., Shanmughun, R., 2016. A study on women empowerment through self-help groups in Erode district. International Journal of Multidisciplinary Research and Modern Education 2(1), 383-388.

Sharma, P., Varma, S.K., 2008. Impact Assessment of Self Help Groups on Quality of Life of Rural Women. International Journal of Family and Home Science 4(1), 57-63.

Shettar, R., 2015. A Study on Issues and Challenges of Women Empowerment in India. Journal of Business and Management 17(4), 13-19.
Tekale, V.S., Jadhav, J.D., Shaikh, J.I., 2014. Empowerment of rural women through self-help group. International Journal of Extension Education 10, 60-64.

Srinivasa, D., Siddagowda, Y.S., 2015. Recent trends in women empowerment: An analysis. International education and research journal. Retrieved from http://ierj.in/journal/ index.php/ierj/article/view/83.

Thangamani, S., Muthuselvi, S., 2013. A study on women empowerment through self-help groups with special reference to Mettupalayam Taluk in Coimbatore district. Journal of Business and Management 8, 17-24. Retrieved from www.iosrjournals.org/ ccount/click. php?id=5166. 